\title{
Wheat Production, Marketing and Consumption in Ethiopia
}

\author{
Regasa Dibaba \\ Ethiopian Institute of Agricultural Research, Assosa Agricultural Research Center, Assosa, Ethiopia \\ P. O. Box 265
}

\begin{abstract}
Wheat is beneficial to man long before the dawn of recorded history. Ethiopia is one of the largest wheat producers in sub-Saharan African next to South Africa. Wheat is one of the most important cereal crops grown in most parts of Ethiopia. It contributes to the major share of daily consumption and cash source. The purpose of this study was to realize the production trends, consumption and utilization patterns, market supply and distribution of wheat in Ethiopia. The review based on data obtained from the Ethiopian Grain Trade Enterprise (EGTE), international agencies such as USDA, FAO and different international websites. The local production of wheat in Ethiopia failed to meet the increasing domestic demands of wheat and wheat products. The flour factories receive allocated amount of wheat grain on monthly basis at price set by the Government; mill it and sale to selected bakeries at pre-determined price. Thus, imported wheat through EGTE has distributed at subsidized price to flour factories which go through consumers to maintain price of bread affordable to low income groups especially in urban areas. The Ethiopian farm households consume about $60 \%$ of wheat produced; $20 \%$ is sold; and the remainder is used for seed, in- kind payments for labor, and animal feed. The wheat consumption trend in Ethiopia is gradually increasing in urban areas due to high population growth (about $2.6 \%$ a year), migration of people to urban areas that increases in condominium living and changes in life styles and it accounts for about $11 \%$ of the national calorie intake in the country. The total consumption of wheat increased by 20 percent in recent years, making it the second most consumed cereal in Ethiopia after Maize.
\end{abstract}

Keywords: Wheat Production, Marketing, Importing, Consumption, Ethiopia.

DOI: $10.7176 / \mathrm{JMCR} / 55-02$

Publication date: April $30^{\text {th }} 2019$

\section{Background of the Study}

As in most developing countries, in Ethiopia agriculture is the dominant sector of the economy. It is the basis of Ethiopian economy, contributing to $46 \%$ of the GDP, over $90 \%$ of exports, and $83 \%$ of employment opportunities (USAID, 2010). It contributes the lion share of the Gross Domestic Product and foreign currency earnings of the country from the sale of agricultural outputs abroad (ECX, 2010). Hence, as it has been for centuries in the past, still being the leading sector at present, in the short run it is believed to remain being the determinant sector to play a dominant role to bring about an overall sustainable economic growth to the country.

Cereal production and marketing are the means of livelihood for millions of households in Ethiopia. It is the single largest sub-sector within Ethiopia's agriculture, far exceeding all others in terms of its share in rural employment, agricultural land use, calorie intake, and contribution to national income (Shahidur, 2010). Wheat is one of the main cereal crops that was beneficial to man and can grow over a wide range of climatic and soil fertility conditions. It has been cultivated in the country for several millennia with little change in farm implements and farming practices among smallholder farmers and constitutes roughly 20 to $30 \%$ of the annual cereal production and plays an appreciable role of supplying the production with carbohydrates, proteins and minerals (Katherine, 2013, Schulthess et al., 2000). It is among the most important cereal grains in Ethiopia in terms of area coverage and production. According to CSA (2014) agricultural sample survey report on area and production, $79.38 \%$ of the total cereal crops area cultivated about $12.94 \%$ was under wheat coverage and where as in production it took from the total cereals contributed $85.81 \%$ of the grain production, wheat accounts $16.60 \%$ in the same year. Wheat production ranks 4 th in area coverage surpassed only by Teff, Maize, and Sorghum and it is the $3^{\text {rd }}$ largest crop in total production (CSA, 2014).

\section{Objectives}

Generally the objective of this study is to investigate the status of wheat production, marketing and consumption trends in Ethiopia.

The specific objectives of the seminar are designed:

1. To investigate wheat production trends and consumption situation in the Ethiopia.

2. To review wheat trade, importing and marketing that underlining current wheat importance in Ethiopia.

\section{Wheat Production in Ethiopia}

The agricultural sector in Ethiopia remained at the vagaries of nature as its performance depends on the timeliness, amount and distribution of rainfall that makes the sector highly vulnerable to drought (ECX, 2010). 
Wheat is an important crop commodity, which could contribute a major part in achieving the country's agricultural objective of food grain self-sufficiency. Since the majority of Ethiopian farmers are resource-poor and smallholder farmers that depend on staple crops for subsistence and as a source of income when they have a marketable surplus. This is particularly true to the major food crops such as wheat grown in the country (CSA, 2014). The optimal temperature is $25^{\circ} \mathrm{C}$; it can be grown in temperatures ranging from $3{ }^{\circ} \mathrm{C}$ to $32^{\circ} \mathrm{C}$ (Briggle, 1980). The optimal rainfall for wheat is between 900-1100 $\mathrm{mm}$ throughout the growing season (Leonard and Martin, 1963).

Wheat is predominantly grown by subsistence farmers under rain-fed conditions and it ranks 4th after teff, maize and sorghum in area coverage and 3 rd in total production important cereal crop productions in the country. Ethiopia is reliant on foreign wheat imports to satisfy its annual domestic demand. Now a day therefore, the Ethiopian government through the Agricultural Growth Program makes active efforts to improve the production and productivity of wheat to increase domestic supply. Most of wheat in Ethiopia is primarily grown in the Amhara, Oromia, Tigray and Southern Nations, Nationalities and Peoples (SNNP) regions (see Appendix). These regions account for more than $90 \%$ of national wheat production. At present, wheat is produced solely under rain-fed conditions. According to ATA (2014) annual report of 2013/14 production season, with 4.8 million farmers involved in wheat cultivation, around 34.3 million quintals of wheat grain across 1.62 million hectares of land produced, making it one of the most important cereal crops in the country. Most of the farming households are involved annually in wheat production, but that still does not satisfy the country's annual domestic demand. According to USDA (2014) grain and feed annual report, Ethiopia's wheat production selfsufficiency is only $75 \%$ and the remaining $25 \%$ of wheat has to be imported commercially and through food aid. Hence, a large quantity of wheat is imported every year to meet the rising domestic consumption demand.

\section{Wheat Production Trend}

Production trend of wheat in Ethiopia shows that high growing pattern starting from 2007. The data from Central Statistical Agency also show that production, area coverage and yield of wheat crop has been increasing during 2004 to 2011 with average annual growth rate of $13.2 \%, 5.9 \%$ and $4.9 \%$, respectively. This growth of wheat production, area harvested and yield is not monotonous. There was a decline in certain years and then there was a big jump of growth from negative in 2006 and 2011 in the country (see Appendix).

\section{Types of Wheat Grown}

There are three major types of wheat: bread (Triticum aestivum), durum (Triticum turgidum durum), and emmer (Triticum turgidum dicoccoides). Emmer wheat is the wild progenitor of the domesticated durum and bread wheat varieties. Bread wheat is the predominant type of wheat grown. A bread wheat account for about half of the area planted, and is generally grown in the highland and semi-highland areas of the Oromia, Tigray, and Amhara regions. Durum wheat covers about $40 \%$ of the national wheat area, but reliable species specific information is limited because production statistics for durum and bread wheat are often confounded. Bread wheat is produced at slightly higher elevations and on better-drained soils than durum wheat (Hailu, 1991).

\section{Distribution and Adoption of Wheat Technologies}

The Ethiopian agricultural research system is coordinated by the Ethiopian Institute of Agricultural Research. Despite this strong research system, seed distribution remains largely informal and farmer-to-farmer exchanges account for as much as $90 \%$ of the seed trade. The government-owned Ethiopian Seed Enterprise (ESE) is the only public sector organization involved in seed production, processing, and distribution. Research institutions provide foundation seed and breeding lines for improved varieties to the ESE, which then multiplies seed in response to demand projections from the regional bureaus of agriculture. The ESE then distributes seed to farmers' cooperative unions via regional bureaus. Despite these efforts, Ethiopia still does not have sufficient seed multiplication facilities, and therefore, farmers are still using low quality seeds. USAID Ethiopia has developed a program to expand seed distribution and to encourage Ethiopian farmers to adopt new seed varieties. This program may help to expand seed distribution and improve wheat seed varieties in the future; however, at present, less than $8 \%$ of farmers are using improved seeds in the wheat growing belt. The Oromia and Amhara regions produce $59 \%$ and $28 \%$ of the country's wheat, respectively, with an additional $10 \%$ coming from the Southern Nations, Nationalities, and Peoples Region and $3 \%$ coming from other regions (USDA, 2014). Generally most farmers were not able to easily access improved seed varieties for wheat and other crops. Only a limited number of farmers had access to improved varieties of wheat. Most of them use local varieties, which have been cultivated for a long period of time.

\section{Opportunities for Small holder Wheat Producers}

In 2013, recognizing that low average yields combined with high demand had been causing Ethiopia to import a significant amount of wheat from other countries. The MoA, with support from the ATA and other partners 
initiated a plan to reverse this trend. Working with the Regional Agriculture Bureaus, a wheat productivity increase strategy was developed, with a goal of reaching at least 1 million farmers in three years with a comprehensive technology package designed to enable them to increase yields by at least $50 \%$.

The government of Ethiopia initiates the program known as the AGP-AMDe with an objective for the wheat value chain which focused on stimulating the productivity and efficiency of farmer cooperative unions (FCUs) and agribusinesses. The program would be intervening the different aspects such as: enhancing production and productivity of farmers through supporting improved input delivery systems; enabling market linkage among millers, processors, aggregators, common interest groups, and wholesalers to increase efficiency; and facilitating transparent transaction through development and dissemination of quality grades and standards, price premiums for higher quality, and improvement of market information system; technology transfer support by assisting seed producers in select FCUs to multiply basic seeds for distribution to producer farmers and avail quality seeds to smallholder farmers and commercial wheat producers. The project has also introduced lowland wheat varieties to low moisture stressed areas in collaboration with different organizations. In addition it enabling access to finance by working with FCUs and cooperatives to develop business plans and long term strategic investment plans; facilitating short term loans through microfinance institutions and commercial banks and technical training support through provision of training on warehousing, logistics and post-harvest handling and wheat farmers are direct beneficiaries of Sell More for More training for farmers.

\section{Constraints of Wheat Production}

Crop yield per area (amount of crop harvested per amount of land cultivated) is the most commonly used impact indicator for agricultural productivity activities. Crop yields are inevitably affected by many factors; these are weather, input price, changes in farming practices, amounts of fertilizer used, quality of seed varieties, and use of irrigation. Badebo et al. (2009) summarized several factors in low yields for durum wheat in Ethiopia. About $85 \%$ of durum wheat cultivars are local varieties which have developed largely by natural processes to adapt to specific areas, rather than formal varieties that have been selectively bred. In addition to yield constraints, the protein quality (and therefore output price) is also affected by low soil fertilizer, excessive rainfall, and cool temperatures.

Transportation infrastructure also is particularly important for wheat due to the concentration of wheat production in the Amhara and Oromia regions, which means that strong distribution channels are necessary to transport wheat to deficit areas that may be hundreds of kilometers away from surplus production zones. The government controls the supply chain in urban areas through the Ethiopian Grain Enterprise (EGTE) distribution, but transportation in rural areas is decentralized. $60 \%$ of grain stocks are held by the Ethiopia Food Security Reserve Administration for use in emergencies; the rest is held by the EGTE, a few mills, and a small amount of private storage.

Another problem that farmers face is weighing the cost of buying inputs that can potentially increase crop yields against the risk of poor rains and low harvest where they would lose the money invested to purchase seed and fertilizer. A lot of farmers are cash constrained, so it makes it difficult for them to buy seed and fertilizer, even if it might be profitable for them. Agricultural potential would be affected by high and reliable rainfall, market access, population density, and investments in connective infrastructure are some factors that affect the rates of production and marketing, (Chamberlin and Schmidt, 2011). The study conducted by EPAR (2012) in the regions of Oromia, Amhara, and Southern Nations, Nationalities and Peoples identified several factors associated with wheat production such as cultivated land, availability of credit, access to market information and average wage of labor.

\section{Wheat Grain Marketing in Ethiopia}

Grain marketing in Ethiopia is important for the agricultural sector for two reasons: i.e. it is the largest of all the agricultural markets, based on volume of output and the geographical area covered; and it involves a large number of participants in production, trade, transportation, storage, and retail (Dessalegn, Jayne, and Shaffer, 1998). Wheat is a major source of food and cash for the peasant sector. In the early 1990's, domestic wheat production accounted for about 50 percent of the total wheat grain requirement. During this period about 53 percent of the total wheat purchase was from overseas (Adanech, 1991). Because of inadequate incentives and low technology inputs, nearly 80 percent of all the wheat produced in the country is consumed on the farm.

Commercial imports of wheat have increased in the last few years, which is likely the result of the government's efforts to stabilize wheat prices following a significant increase in domestic food prices. These wheat imports account for roughly thirty-three percent of the wheat market. The flour mills get the remainder of the wheat supply from the local market (USDA, 2013). Hence, a large quantity of wheat is imported every year to meet the rising domestic consumption demand. Domestic wheat would be able to compete with imported wheat if policies were more favorable for producers and other operators along the market chain. Promoting the use of more productive inputs and new technologies, reducing market in costs, would be encouraging domestic 
wheat supply more for overcoming the current deficit in wheat grain.

Participants in the Ethiopian wheat market include wholesalers, retailers, part-time farmer-traders, brokers, processors, cooperatives, the EGTE, and private consumers. The EGTE purchases grain from farmers to stabilize markets and encourage increased outputs. The study conducted by EPAR (2012) show that the majority of farmers sold wheat at markets inside their district; $66 \%$ of producers sold their wheat at the nearest market outside of the peasant association (PA), 20\% sold at markets within the PA, and only 11\% sold at district town markets. About $51 \%$ sold to wholesalers, $43 \%$ to retailers, and only $6 \%$ directly to consumers. The same study indicated that only about $20 \%$ of domestically produced wheat was sold, but commercialization rates varied across the country. As of CSA 2007, 60\% of the population in Ethiopia lived in areas with high market access. Commercialization rates appear higher in Oromia, SNNP, and Amhara regions.

\section{Wheat Importing in Ethiopia}

The government of Ethiopia started importing wheat in 2008/9 market year through EGTE which increased the domestic supply of wheat at a subsidized price and lowered the domestic market prices. For importers, wheat importing is no longer a profitable business because importers cannot compete with the subsidized wheat the GOE imports via EGTE, price increases in the international market, and problems in obtaining foreign exchange. In marketing year 2011/12, EGTE imported wheat mainly from Russia and Argentina and also food aid mainly from the United States, (USDA, 2013) while in market year 2012/13; EGTE imported more wheat, primarily from India, and around 26 percent of food aid, which was from the US (see table 1). Ethiopia remains one of the largest recipients of food aid in Africa, receiving around $27 \%$ of the global food aid given to sub-Saharan Africa (USDA, 2014).

Table 1. Total wheat imports by country of origin (1000 MT)

\begin{tabular}{lccc}
\hline \multicolumn{1}{c}{ Country of Origin } & \multicolumn{3}{c}{ Marketing year } \\
\cline { 2 - 4 } & $\mathbf{2 0 1 0 / 2 0 1 1}$ & $\mathbf{2 0 1 1 / 2 0 1 2}$ & $\mathbf{2 0 1 2 / 1 3}$ \\
\hline Russian Federation & 335 & 388 & - \\
USA & 207 & 261 & - \\
Argentina & - & 212 & - \\
Brazil & 24 & 120 & 673 \\
India & - & - & 49 \\
Italy & 89 & - & - \\
Oman & 45 & - & - \\
Pakistan & 33 & - & - \\
Belgium & - & 42 & - \\
Turkey & 14 & - & - \\
China & - & 25 & - \\
Others & 49 & 2 & $\mathbf{9 8 4}$ \\
\hline Total & $\mathbf{7 9 6}$ & $\mathbf{1 0 5 0}$ & \\
\hline
\end{tabular}

Source: Ethiopia Revenue and Custom Authority as cited by USDA, 2014.

All wheat imports from the United States are for food assistance rather than commercial imports. According to USDA FAS (2012), barriers to commercial imports of U.S. wheat include millers' lack of access to foreign currency, price, millers' inability to handle large volumes in shipments from the U.S., and lack of silo capacity at the port of Djibouti.

Table 2. Ethiopian Wheat imports-Commercial vs. Food Aid (1000 MT)

\begin{tabular}{lcccc}
\hline \multicolumn{1}{c}{ Import } & \multicolumn{4}{c}{ Marketing Year } \\
\cline { 2 - 5 } & $\mathbf{2 0 1 0 / 1 1}$ & $\mathbf{2 0 1 1 / 1 2}$ & $\mathbf{2 0 1 2} / \mathbf{1 3}$ & $\mathbf{2 0 1 3} / \mathbf{1 4}$ \\
\hline GOE Commercial import & 76 & 750 & 650 & 400 \\
Food assistance & 720 & 300 & 550 & 552 \\
Total Wheat Import & $\mathbf{7 9 6}$ & $\mathbf{1 0 5 0}$ & $\mathbf{1 1 0 0}$ & $\mathbf{9 5 2}$ \\
\hline
\end{tabular}

Source: Ethiopia Revenue and Custom Authority as cited by USDA, 2014

The Ministry of Trade (MOT) controls the supply chain of imported wheat in urban areas through EGTE. Only 30 percent of the total 216 major flour mills in the country are getting subsidized wheat for their mills from EGTE, and the price of this subsidized flour is capped by the MOT. Mills located outside of the capital prefer to buy wheat from the local market due to lower transportation costs and because the price of flour made by those mills is not capped. The Ethiopian Grain Trade Enterprise (EGTE) plays a big role in wheat marketing, importing wheat and distributing to millers and consumers to temporarily address the high prices and inflation created by the gap between demand and supply. 
Table 3. Local wheat production and imports from 2002-2013 (million MT)

\begin{tabular}{ccccc}
\hline Year & Production & Import & Total \\
\hline 2002 & 1.1 & 0.5 & $\mathbf{1 . 6}$ \\
2003 & 1.6 & 1.6 & $\mathbf{3 . 2}$ \\
2004 & 2.2 & 0.6 & $\mathbf{2 . 8}$ \\
2005 & 2.2 & 1.0 & $\mathbf{3 . 2}$ \\
2006 & 2.5 & 0.3 & $\mathbf{2 . 8}$ \\
2007 & 2.3 & 0.4 & $\mathbf{2 . 7}$ \\
2008 & 2.5 & 1.1 & $\mathbf{3 . 6}$ \\
2009 & 3.1 & 1.2 & $\mathbf{4 . 3}$ \\
2010 & 2.9 & 1.1 & $\mathbf{4}$ \\
2011 & 2.9 & 1.1 & $\mathbf{4}$ \\
2012 & 3.4 & 1.0 & $\mathbf{4 . 4}$ \\
\hline
\end{tabular}

Source: CSA, ERCA Import data and ATA Annual Report 2013.

\section{Wheat Marketing Problem}

Agricultural marketing is a very important factor in economic development and lack of a well-functioning agricultural market and marketing system severely hinders the increase of social welfare, income distribution, and food security of developing countries. Moreover markets and marketing system do not develop simultaneously with economic growth. Markets and marketing system should be organized deliberately to enable economic development, (Wolday, 1994).

Grain marketing in Ethiopia is characterized by weak institutional support and inadequate infrastructure. With no effective systems in place for identifying grades and standards, existing market information systems are of limited value to famers and other actors along the marketing of grain produce. The efforts of increasing agricultural production and productivity have to be accompanied by a well- performing marketing system which satisfies consumer demands with the minimum margin between producers and consumer prices. Higher prices for producer can encourage farmers to adopt new technologies, increase production (Wolday, 1994). However, there are external and internal problems that influence the marketing efficiency in Ethiopia. This has to do with lack of pertinent market information, development of marketing institutions and marketing infrastructure such as storage, transportation etc. Indeed, producers and traders have difficulty making sound decisions based on price information that does not specify grades and standards. Since mixing different grades of grain compromises quality, the lack of common standards and grades has also hindered the production and marketing of wheat in the country.

Furthermore, trade associations are weak and have limited capacity to regulate them; establish and enforce standards; and modernize wheat marketing. High transport costs severely impact farmers located far away from wholesale markets (points of competition) such as Addis Ababa. High costs are due to long distances, poor infrastructure, limited processing and the lack of bulk handling and transporting systems. Indeed, grain is transported in small trucks at a high cost per unit. Currently, only about 21 percent of Ethiopia's total wheat production is marketed.

\section{Improvement Need to Market Institution in Ethiopia}

Improving market and transport infrastructure would increase incentives for wheat farmers to market their produce. Lowering transaction and transportation costs would also help reduce the cost of inputs and support services, and increase farm gate prices. These would help improve incentives for producers to market their products. To furnish this improved information and marketing facility enables farmers to plan their production more in line with market demand, to schedule their harvest at the most profitable time, to decide which market to sell their produce to and bargain on a more even footing with traders and it also enables traders to move their produce profitably from a surplus to deficit market and to make decisions about the economics of storage, where technically possible.

\section{Importance and Consumption of Wheat Crop Importance of Wheat in Ethiopia}

Wheat is today, one of the most important of all cultivated plants, more nutritious of cereals and continue to be most important food grain source to human nutrition (Pearson 1967; Harlan, 1981; and Curtis, 2002) and its contribution to the human diet puts it clearly in the first rank of plants that feed the world (Harlan, 1981). Worldwide, wheat is used as human food, seed, livestock feed, and as an industrial raw material (Tanner and Raemaekers, 2001). Wheat sustains millions of lives and livelihoods, accounting for one-fifth of humanity's food, and it has the highest content of protein of all the staple foods and contains essential minerals, vitamins, and 
lipids. It is the primary source of protein in developing countries, with 1.2 billion people dependent on wheat for survival (CIMMYT, 2011). Wheat provides nearly 55 percent of carbohydrates and more than 20 percent of the calories and protein consumed globally (Bushuk, 1998).

Wheat is used for the manufacture of flour for different purposes. Wheat is known to be a major source of energy and protein. It is used in the preparation of a wide range of products such as the traditional fermented thin bread ("injera"), regular bread ("dabo"), local beer ("tella"), "dabokolo","ganfo", "kinche" and several other local food items. Bread, biscuits and pasta products such as macaroni, spaghetti and noodles are some of the industrial products. Wheat is not only for making bread, biscuit and pastry products, but also for the production of starch and gluten. The raised bread loaf is possible because the wheat kernel contains gluten, an elastic form of protein that traps minute bubbles of carbon dioxide when fermentation occurs in leavened dough, causing the dough to rise (Hanson et al., 1982). In most parts of the country, families prefer to use teff to make injera (fermented thin bread) and sometimes to make porridge. Because of the price escalation of teff compared to wheat and of the ease of preparation of wheat, most middle and lower class populations are shifting to greater wheat consumption (USDA, 2014). The value of the straw is also considerable. It is estimated that wheat straw contributes about one million tons or $8.3 \%$ of the total annual crop residue (Said and Adugna, 1991). The stacked straw is mainly fed to animals during the dry season and the stubble is grazed about the same time. Additionally, wheat straw is commonly used as a roof thatching material and as animal feed. The straw is good source for animal feed and is also used for thatching roofs (USDA, 2014).

\section{Consumption Trends of Wheat}

Wheat is an important source of calories in Ethiopian diets, particularly in rural households Wheat accounts for 9-20\% of the calories consumed in Ethiopia, depending on the source, and accounts for a larger portion of daily caloric intake in low-income and rural households. Bread wheat is commonly used in leavened and unleavened breads, noodles, cookies, and cakes. Durum wheat is more commonly used in semolina, pasta, and many other local dishes. Due to its smaller size and weight, bread wheat can be broken into finer flour and has a softer texture, making it popular in agro-industries. Over the past twenty years, wheat production and consumption have both increased in Ethiopia. The Ethiopian government has played an active role in wheat markets, such as making large investments in extension programs and adopting protectionist policies to ensure government control of all commercial grain imports. Despite these efforts, Ethiopia is expected to face a growing supply deficit in the absence of increased domestic productivity and/or changes to government policy.

Food consumption patterns in Ethiopia are diverse, and unlike in many other countries, no single crop dominates the national food basket (e.g., rice in most of East Asia, maize in Latin America, or cassava in Central Africa). The Ethiopian food basket consists of a wide variety of grains and other staples. However, consumption levels and mixes of these grains vary widely according to differences in agro-ecology, socioeconomic levels, and livelihood strategies and difference in times of the year. As in many other traditional societies, dietary preferences and consumption patterns are heavily influenced by cultural values and traditions and may not necessarily reflect availability or the nutritional quality of specific food items (IFPRI, 2011). Total and per capita wheat consumption has gradually increased in Ethiopia.

The majority of wheat consumption is for food; about $10 \%$ of grain production is held for planting. The Ethiopian Commodity Exchange estimates that household consumption accounts for about $60 \%$ of domestically produced wheat, $20 \%$ for sales, and a combination of seed, in-kind payments for labor, and animal feed for the remainder. The share of wheat in total cereal consumption increased by 20 percent in recent years, making it the second most consumed cereal in Ethiopia after corn (maze). Ethiopian household diet on average, wheat accounts for approximately $200 \mathrm{kcal} /$ day in urban and whereas $310 \mathrm{kcal} /$ day in rural areas. However, the consumption of wheat has gradually increased in urban areas because of high population growth (about $2.6 \%$ a year), migration of people to urban areas, and increases in condominium living (USDA, 2014). Wheat accounts for about 11 percent of the national calorie intake in the country. 
Table 4. Consumption Trends of Wheat in Ethiopia.

\begin{tabular}{cccc}
\hline Year & Unit of Measurement & Domestic Consumption & Growth rate \\
\hline 2000 & $(1000 \mathrm{MT})$ & 2712 & NA \\
2001 & $(1000 \mathrm{MT})$ & 2230 & $-17.77 \%$ \\
2002 & $(1000 \mathrm{MT})$ & 1683 & $-24.53 \%$ \\
2003 & $(1000 \mathrm{MT})$ & 2396 & $42.36 \%$ \\
2004 & $(1000 \mathrm{MT})$ & 2608 & $8.85 \%$ \\
2005 & $(1000 \mathrm{MT})$ & 2500 & $-4.14 \%$ \\
2006 & $(1000 \mathrm{MT})$ & 2763 & $10.52 \%$ \\
2007 & $(1000 \mathrm{MT})$ & 2730 & $-1.19 \%$ \\
2008 & $(1000 \mathrm{MT})$ & 3800 & $39.19 \%$ \\
2009 & $(1000 \mathrm{MT})$ & 3950 & $3.95 \%$ \\
2010 & $(1000 \mathrm{MT})$ & 3715 & $-5.95 \%$ \\
2011 & $(1000 \mathrm{MT})$ & 4219 & $13.57 \%$ \\
2012 & $(1000 \mathrm{MT})$ & 4450 & $5.48 \%$ \\
2013 & $(1000 \mathrm{MT})$ & 5100 & $14.61 \%$ \\
2014 & $(1000 \mathrm{MT})$ & 5400 & $5.88 \%$ \\
\hline
\end{tabular}

Source: USDA, 2015

\section{Current Scenario of Food Expenditure on Wheat Grain}

Food is first necessity to survival. It is among the most important ingredients for human development and national stability. The accessibility or existence of food is a big issue in livelihood and it is obvious that any shock in the existence of food affects the nation negatively. A country which can produce sufficient food can be indicated as low level of infant (adult) mortality, low level of malnutrition; good health status, strong and active citizen and this will help that country to grow faster as it has capable citizens that can produce effectively and efficiently. This makes a circle of balanced diet, high productivity, and sufficient food. As some anecdotal evidences indicate, aggregate food production at global level is more than enough for all human population, the only problem is distribution. With respect to consumption, table 5 shows that wheat is more preferred in Tigray, Amhara, and Afar areas and in contrast wheat have very low shares in the total food expenditure of households in Addis Ababa, constituting only 3.4 percent, indicating low demand for wheat in the city (EDRI, 2013).

Table 5. Share of wheat in total food expenditure by region

\begin{tabular}{llc}
\hline S.No. & Region & Wheat (\%) \\
\hline 1 & Tigray & 13.1 \\
2 & Amhara & 10.4 \\
3 & Afar & 10.0 \\
4 & Somali & 9.7 \\
5 & Oromia & 9.6 \\
6 & Dire Dawa & 7.4 \\
7 & Harari & 7.0 \\
8 & SNNP & 5.5 \\
9 & Addis Ababa & 3.4 \\
10 & Benishangul Gumuz & 0.9 \\
\hline
\end{tabular}

Source: Berhane, Paulos, and Tafere (2011) as cited by EDRI, 2013.

\section{Nutritional Values of Wheat}

In terms of quality, wheat provides an optimum amount of energy, protein, calcium and iron. Chemically, wheat contains $339 \mathrm{kcal}$ of energy, $10.3 \mathrm{~g}$ of protein, $49 \mathrm{mg}$ of calcium, and $1.5 \mathrm{mg}$ of iron/100 $\mathrm{g}$ of whole grain (Aberra Bekele, 1991 as cited by Teklu). The protein: energy ratio of wheat is $12 \%$ as compared to $10.8 \%$ of barley, $10.7 \%$ of teff, $10.5 \%$ of sorghum and $10.1 \%$ of maize.

Wheat is a good source of protein and other nutrients, but nutritional content is highly variable. As shown from table 6 whole wheat has the highest protein level and contains more iron, riboflavin, and niacin. The table also demonstrates the negative relationship between nutrient content and the degree of milling, with less processed cereals retaining more nutrients. White wheat flour does not contain most of the germ and outer layers that contain some of the protein and the majority of B vitamins and other nutrients. The degree of wheat processing also has a significantly negative effect on antioxidant content and bioavailability; consumption of whole-grain wheat has been associated with a reduced risk for several chronic diseases due to those antioxidant properties and insoluble fiber content. 
Table 6. Nutritional Composition of Wheat (per 100 grams)

\begin{tabular}{|c|c|c|c|c|c|c|c|c|}
\hline Food & $\begin{array}{l}\text { Energy } \\
\text { (kcal) }\end{array}$ & $\begin{array}{l}\text { Protein } \\
\text { (g) }\end{array}$ & $\begin{array}{l}\text { Fat } \\
\text { (g) }\end{array}$ & $\begin{array}{l}\text { Calcium } \\
\text { (mg) }\end{array}$ & $\begin{array}{l}\text { Iron } \\
\text { (mg) }\end{array}$ & $\begin{array}{l}\text { Thiami } \\
\text { (mg) }\end{array}$ & $\begin{array}{c}\text { neRibofla } \\
\text { (mg) }\end{array}$ & $\begin{array}{c}\text { vinNiaci } \\
\text { (mg) }\end{array}$ \\
\hline \multirow{2}{*}{$\begin{array}{l}\text { Wheat, whole } \\
\text { Wheat flour, white }\end{array}$} & 323 & 12.6 & 1.8 & 36 & 4.0 & 0.30 & 0.07 & 5.0 \\
\hline & 341 & 9.4 & 1.3 & 15 & 1.5 & 0.10 & 0.03 & 0.7 \\
\hline
\end{tabular}

Sources: Latham, 1997; EPAR, 2010; White and Broadley, 2009 (*Reported values are the average of estimates from multiple sources).

\section{Wheat Processing Factories in Ethiopia}

There are around 216 flour mills in Ethiopia, with a total production capacity of about 4.2 million tons of wheat flour a year. Almost a third of these mills are located in Addis Ababa. Mills are able to obtain wheat through two channels namely subsidized wheat from the EGTE and from domestic production on the open market, whose price is higher than imports. The state-owned EGTE controls all commercial wheat imports and makes wheat available to millers at a subsidized price; this accounts for roughly a quarter of the wheat market and the rest of the market is supplied from domestic production, whose price is not controlled and which price is higher than imported wheat, (USDA, 2014). Wheat can be easily and safely stored for long periods of time; and has wide adaptability. It also requires minimal processing for consumption and is easily transported (Nuttonson, 1955).

\section{CONCLUSION}

Ethiopia is the second largest wheat producer in Sub-Saharan Africa, next to South Africa. In Ethiopia wheat is predominantly produced by smallholders with average landholdings of less than one hectare. A relatively large percentage of wheat $(5-10 \%)$ is produced on large-scale farms in the Arsi-Bale wheat belt. Both durum and bread wheat have currently produced roughly 40 and 60 percent respectively constitute the entire wheat production in the country. Similar to any other agricultural crop produced in the country, wheat is produced solely under rain fed condition in both main rains (meher) falling from June to September and short rains (belg) falling from February to April. Almost all wheat production of the country comes from four major wheat producing regions; Oromia, Amhara, SNNPR and Tigray regions.

Improvement in productivity and subsequent effective marketing of wheat produce in potential wheat producing areas can be a major milestone in the fight against poverty in the rural areas. There is no doubt that there are many challenges associated with developing market opportunities and profitable market structures. First and foremost is the need to secure a consistent supply of wheat grain that meets required quality standards and quantity requirements as well as price and cost structures that make wheat production economically viable to smallholder producers. Improved market linkages that increase the volume and value of traded wheat produce between rural agricultural households and the rest of the domestic, regional and national economy would benefit both smallholder producers and consumers. Reduced marketing costs resulting from development of enhanced market linkages have the potential for increasing farm-gate prices while reducing consumer prices.

Production of wheat can be boosted using improved technologies and farm management practices. This is important for meeting desired quality standards in local and terminal markets. However, the existing marketing systems in the country do not always value quality properly, especially at the lower end of the market outlets. This makes it difficult for farmers to appreciate and internalize quality issues as prices may not always reward good behaviour in maintaining quality. There is a need for a more efficient marketing system that helps reduce transaction costs and create incentives for smallholder producers to adopt new technology for improving productivity and enhancing quality and reliability of supply.

Ethiopia is a net importer of wheat, but only through state-controlled channels. The Ethiopian government is heavily involved in the trade of wheat. Although private imports are not expressly banned, government restrictions on access to foreign currency have effectively stopped private sector imports despite low tariffs; there have not been any private sector grain imports (with the exception of some wheat shipments brought in under USDA Food for Progress agreements) since April 2008. As a result, all commercial imports come through the state-owned Ethiopian Grain Trade Enterprise (EGTE). The EGTE limits imports to ensure that domestic production is consumed first.

The demand of wheat in the country is highly rising over years. Total supply of wheat in a particular year in the country comes about 65 percent from production, $26 \%$ from import and $9 \%$ from the stock carried over. Almost the entire supply of wheat in the country has been demanded for domestic consumption. Large proportion from the total supply was demanded by household agricultural producers and consumers for their household consumption and also food processing industries (micro and small scale and, large and medium scale food processing manufacturing) have a large volume of wheat demand to prepare flour, pasta and macaroni, biscuits and bread and other fabricated food types. Wheat production trend has been increasing in volume recently due to good government supportive initiatives, increment of cultivated area for wheat production and 
the increasing development in use of agricultural inputs including improved wheat varieties and fertilizers. Although over 4.5 million households are involved annually in wheat production the country, but that still does not satisfy the country's annual domestic demand. Hence, a large quantity of wheat is imported every year to meet the rising domestic consumption demand.

\section{REFERENCES}

Agricultural Transformation Agency, 2013/2014. Annual Report Transforming Agriculture in Ethiopia.

Badebo, A., Gelalcha, S., Ammar, K., \& Nachit, M. M. (2009). Overview of durum wheat research in Ethiopia: Challenges and prospects. 2009 Technical Workshop, Borlaug Global Rust Initiative, Cd. Obregón, Sonora, Mexico, 17-20 March, 2009.

Briggle, L.W. 1980. Origin and botany of wheat. In E. Häfliger, ed. Wheat documenta cibageigy, p. 6-13. Basle, Switzerland.

Bushuk W. (1998). Wheat breeding for end-product use. Euphytica 100:137-145.

Central Statistical Authority.2011. Agricultural Sample Survey 2001/2002.

Report on Area and Production of Major Crops Volume 1. CSA, Addis Ababa, Ethiopia. 134 pp.

CIMMYT (2011). Wheat-Global alliance for improving food security and the livelihoods of the resource-poor in the developing world. August 30, 2011.

Chamberlin, J., \& Schmidt, E., 2011. Ethiopian agriculture: A dynamic geographic perspective. IFPRI. Retrieved from $h t t p: / / w w w . i f p r i . o r g / s i t e s / d e f a u l t / f i l e s / p u b l i c a t i o n s / e s s p w p 17 . p d f$

Curtis B.C. 2002. Wheat in the World. In Curtis Rajarm B.C.S. and Gomez H. McPherson, (Edits), Improvement and Production, FAO, Rome.

Dessalegn, G., T.S. Jayne, and J.D. Shaffer, 998. Market Structure, Conduct, and Performance: Constraints on Performance of Ethiopian Grain Market. Grain Market Research Project Working Paper 8. Addis Ababa, Ethiopia.

Ethiopian Commodity Exchange Authority, 2010. Research report on 2009/10 fiscal year Meher season grain and coffee production, supply and prospects for the near future.

Ethiopian Development Research Institute, 2012. Dynamics of Food Price Trends and Policy Options in Ethiopia report for ASARECA's Project.

EPAR. (2010b). Brief No. 114 - Crops \& climate change: Wheat. Evans School Policy Analysis and Research, 2012. Wheat Value Chain: Prepared for the Agricultural Policy Team. Ethiopia. EPAR Brief No. 204.of the Bill \& Melinda Gates Foundation.

EPAR. (2012). Brief No. 98-Yield gap productivity potential in Ethiopian agriculture: Staple grains \& pulses.

Fasil Kelemework, Teklu Erkosa, Teklu Tesfaye and Assefa Gizaw (2000). On farm demonstration of improved durum wheat varieties under enhanced drainage on vertisols in central

Hailu Gebremariam. 1991. Wheat production and research in Ethiopia. A Historical Perspective. Addis Ababa, Ethiopia:IAR/CIMMYT. Pp. 1-16.

Hanson H., Noman E.B.and R.G. Anderson.1982. Wheat in the Third World.

International West View Maize and Wheat Improvement Center, Press; Boulder, Colorado,USA, West views Press.

Harlan R.J. 1981.The early history of wheat earliest traces to the sack of Rome, In L.T. Evans and W.J. Feacu UK (edits), Wheat Science: Today and Tomorrow, Cambridge University press, Cambridge.

IAR (Institute of Agricultural Research) (1992).14th National crop Improvement conference, Addis Ababa, Ethiopia.

International Food Policy Research Institute (IFPRI), 2011. Ethiopia Strategy Support Program II, Ethiopia (ESSP II) .Working Paper No. 23

Katherine Margaret Nelson, 2013. Analysis of Farmer Preferences for Wheat Variety Traits in Ethiopia: A Gender-Responsive Study. A Thesis Presented to the Faculty of the Graduate School of Cornell University.

Kohl, R.L. and Uhl, J.N., 1985, Marketing of Agricultural Product, 5th Edition, Collier Macmillan, USA. 624p

Kotu, B., H. Verkuijl, W. Mwangi, and D. Tanner (2000). Adoption of Improved Wheat Technologies in Adaba and Dodola Woredas of the Bale Highlands, Ethiopia. Mexico, D.F.: CIMMYT and the Ethiopian Agricultural Research Organization (EARO).

Langer M.R.H. and Hill G.D.1982. Agricultural Plants, Cambridge University Press, Cambridge.

MoARD, Export Performance Report of 2008/09.

Nuttonson, M.Y. (1955). Wheat-climatic relationships and the use of phenology in ascertaining the thermal and photothermal requirements of wheat. Washington, DC, American Institute of Crop Ecology.

Pearson C. Lorentz, .1967. Principles of Agronomy, Reinhold, New York.

Shahidur Rashid, 2010. International Food Policy Research. African Agricultural Marketing Project. Staple Food Prices in Ethiopia Prepared for the COMESA policy seminar on "Variation in staple food prices: Causes, consequence, and policy options”, Maputo, Mozambique. Institute, Addis Ababa, Ethiopia. 
Schulthess U, Feil B, JutzI SC (2000).Yield independent variation in grain nitrogen and phosphorus concentration among Ethiopian wheat. Agron. J.89 (3) 497-506

Tanner D. and R. Raemaekers, 2001. Wheat: Triticum Spp., In Romain H.Raemalker's (edit.) Crop production in tropical Africa Directorate General for International Cooperation, Brussels, Belgium

United State Aid for International Development (USAID), 2010 .Ethiopia 2010 fiscal year Implementation Plan report, feed the world initiative. Washington, USA

United States Department of Agriculture, 2014. USDA Foreign Agricultural Service. Global Agricultural Information Network. Grain and Feed annual report. Number:ET-1401.

United States Department of Agriculture, 2015. Domestic consumption of Wheat in Ethiopia. http://www.usda.gov/ indexmundi.com

Wolday, Amha, 1994. Food Grain Marketing Development in Ethiopia after Reform 1990, A Case Study of Alaba Siraro, The PhD Dissertation Presented to Verlag Koster University.Berlin 293p.

World Bank, (2012). World Development Indicators database, World Bank. http://databank.worldbank.org

\section{ANNEXES}

Table 7. Annual wheat production and area harvested by major regions

\begin{tabular}{|c|c|c|c|c|c|c|c|c|}
\hline \multicolumn{2}{|c|}{ Production Oromia } & & \multicolumn{2}{|l|}{ Amhara } & SNNP & \multicolumn{3}{|c|}{ Tigray } \\
\hline Year & $\begin{array}{l}\text { Area } \\
\text { (million } \\
\text { ha) }\end{array}$ & $\begin{array}{l}\text { Production } \\
\text { (million Qt) }\end{array}$ & $\begin{array}{l}\text { Area } \\
\text { (million } \\
\text { ha) }\end{array}$ & $\begin{array}{l}\text { Production } \\
\text { (million } \\
\text { Qt) }\end{array}$ & $\begin{array}{l}\text { Area } \\
\text { (million } \\
\text { ha) }\end{array}$ & $\begin{array}{l}\text { Production } \\
\text { (million Qt) }\end{array}$ & $\begin{array}{l}\text { Area } \\
\text { (million } \\
\text { ha) }\end{array}$ & $\begin{array}{l}\text { Production } \\
\text { (million Qt) }\end{array}$ \\
\hline $2005 / 06$ & 0.82 & 13.2 & 0.43 & 6.1 & 0.12 & 1.8 & 0.08 & 1.0 \\
\hline $2006 / 07$ & 0.81 & 14.3 & 0.43 & 6.8 & 0.12 & 1.92 & 0.1 & 1.5 \\
\hline $2007 / 08$ & 0.77 & 13.4 & 0.43 & 6.2 & 0.12 & 0.0 & 0.1 & 1.5 \\
\hline $2008 / 09$ & 0.79 & 15.2 & 0.43 & 6.5 & 0.11 & 2.2 & 0.1 & 1.4 \\
\hline $2009 / 10$ & 0.86 & 16.8 & 0.55 & 9.0 & 0.16 & 3.1 & 0.11 & 1.4 \\
\hline $2010 / 11$ & 0.82 & 15.8 & 0.50 & 8.2 & 0.13 & 2.4 & 0.1 & 1.9 \\
\hline $2011 / 12$ & 0.74 & 16.8 & 0.46 & 7.7 & 0.13 & 2.6 & 0.11 & 2.0 \\
\hline $2012 / 13$ & 0.87 & 20.3 & 0.50 & 8.9 & 0.14 & 3.0 & 0.11 & 2.1 \\
\hline Total & 6.48 & 125.8 & 3.73 & 59.4 & 1.03 & 17.02 & 0.81 & 12.8 \\
\hline
\end{tabular}

Source: CSA, 2005-06 to 2012-13 and ATA Annual Report, 2014

Table 8. Area harvested and production trends of wheat in Ethiopia

\begin{tabular}{ccccccc}
\hline Year & Area (000'ha) & $\begin{array}{c}\text { \% } \\
\text { change }\end{array}$ & $\begin{array}{c}\text { Production } \\
\text { (000'Quintals) }\end{array}$ & $\begin{array}{c}\text { \% } \\
\text { change }\end{array}$ & $\begin{array}{c}\text { Yield } \\
\text { (000'Qt/ha) }\end{array}$ & $\begin{array}{c}\text { \% } \\
\text { change }\end{array}$ \\
\hline 2004 & 1393 & - & 25430 & - & 18 & - \\
2005 & 1526 & 9.55 & 23942 & -5.85 & 16 & -11.11 \\
2006 & 1694 & 11.01 & 33368 & 39.37 & 20 & 25.00 \\
2007 & 1767 & 4.31 & 37764 & 13.17 & 21 & 5.00 \\
2008 & 1768 & 0.06 & 37497 & -0.71 & 21 & 0.00 \\
2009 & 1772 & 0.23 & 39325 & 4.88 & 22 & 4.76 \\
2010 & 1963 & 10.78 & 38972 & -0.90 & 20 & -9.09 \\
2011 & 2055 & 4.69 & 52189 & 33.91 & 25 & 25.00 \\
\hline Change b/n 2004 \& 2011(\%) & $\mathbf{4 7 . 5}$ & & $\mathbf{1 0 . 5}$ & & $\mathbf{3 9 . 1}$ & \\
Average Annual \% change & $\mathbf{5 . 9}$ & & $\mathbf{1 3 . 2}$ & & $\mathbf{4 . 9}$ & \\
\hline Soura
\end{tabular}

Source: Author's calculated using CSA database (2011) and EDRI (2012) 